\title{
مصطلح التماسك النصي في التراث اللغوي العربي: مقاربة نصية
}

$$
\begin{aligned}
& \text { د. عز الدين هبيرة } \\
& \text { كلية الآداب واللغات } \\
& \text { قسم اللغة العربية } \\
& \text { جامعة الإخوة منتوري قتسنطينة }
\end{aligned}
$$

تنشأ الدراسات النصية العربية علما مكتملا يحقق التماسك النصي

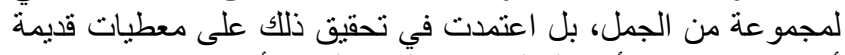

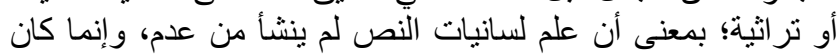

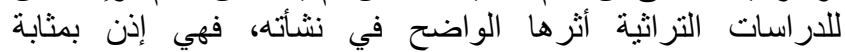

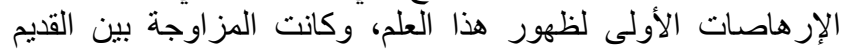

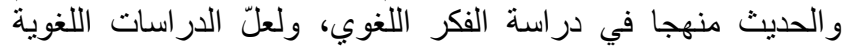

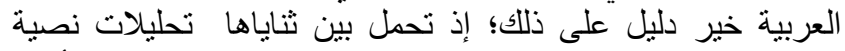

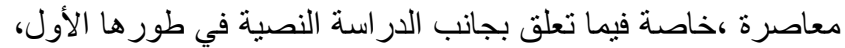
بعيدا عن المصطلح اللساني المتداول الآن.

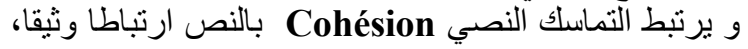

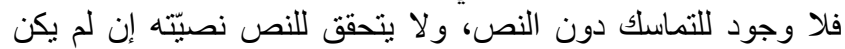

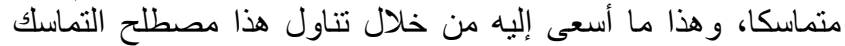

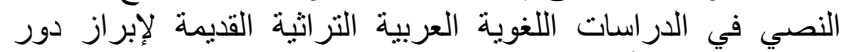
العرب في وضع أسس هذه النظرية.

\section{مقدّمة:}

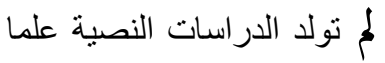

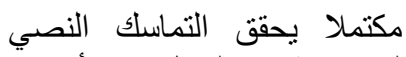

لمجموعة من الجمل، كما أنها قد الفئ

اعتمدت في تحقيق ذللك على منى إنى

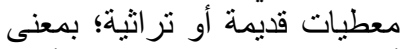

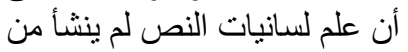

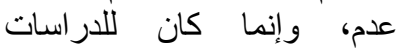

التر اثية أثرها الو اضما كانح في نشأته،

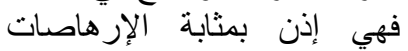

الأولى لظهور هذا العلم، سواء

أكان ذللك على مستوى الارلى استات

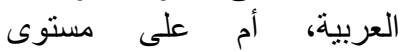

الدراسات الغربية.

\section{Abstract:}

The textual study didn't generate a complete note that achieves the textual consistency of a set of sentences, rather; relied on an old or traditional data.

In other words, the linguistics of the text did not arise from the lack of science.

The combination of the old and the modern was an approach in the study of linguistic studies is good proof of that;

Because it contains contemporary textual analysis,especially about the study of text in the first phase away from the current linguistic term, the text is closely related; there is no coherent.

This is what I seek by addressing this term of textual coherence in the studies of ancient traditional Arabic language to show the Arabs role in the foundation of this theory. 
فكانت المزاوجة بين القديم والحديث منهجا في دراسة الفكر الإنساني في عمومه، والفكر اللغوي

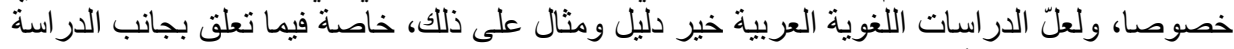

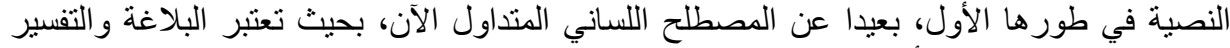
و النقد والنحو وما فيها من أفكار تحمل بين ثناياها تحلبلآت نصية معاصرة.

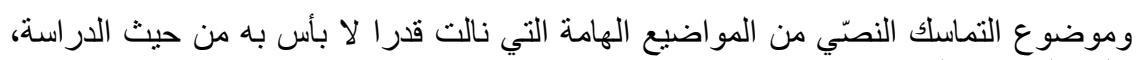
و واهتمام علماء لسانيات النص به، النهي

و هذا يعني أنه أحد أسس البحث النصي الحديث، حيث تتطلق الدراسات اللسانية المعاصرة من أن النص بنية منمأسكة ووحدة كلية شاملة.

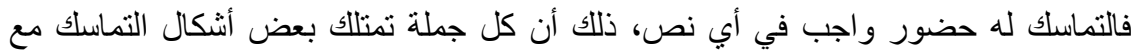

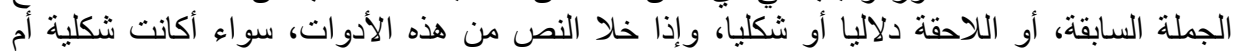
دلالية، فإنّه يصبح جملا متجاورة ولا يربط بينها رابط، ويصبح النص هيكلا خاليا من الروح الفنية.

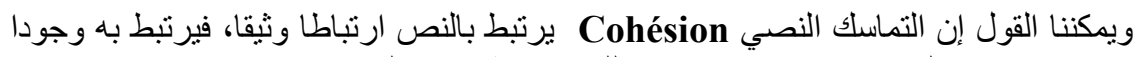

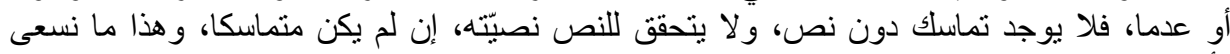

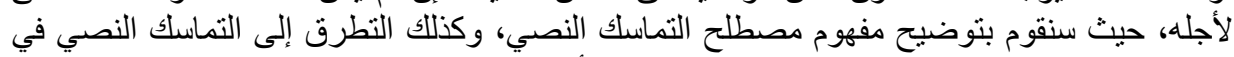
الدراسات العربية القديمة لإبراز دور العرب في وضع أسس هذه النظرية.

وسيتناول هذا المقال العناصر الآتية:

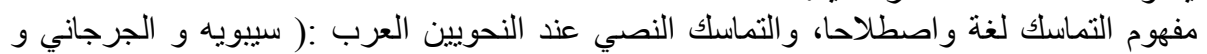

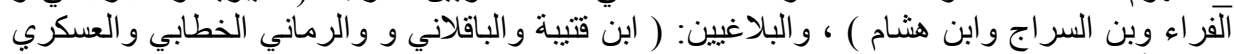

1

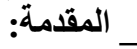
نحاَول في هذا البحث التعرف على المعنى اللغوي لهذا المصطلح، الذي أخذ الكثير من المعاني

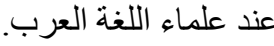

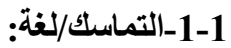

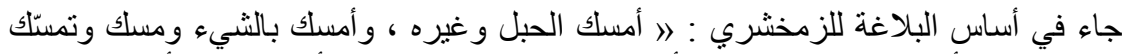

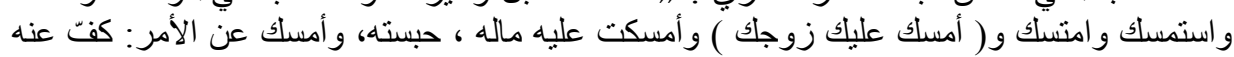

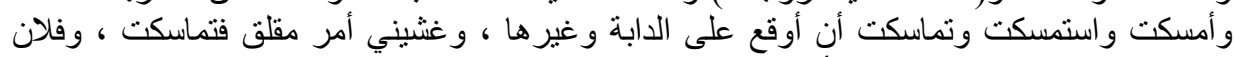

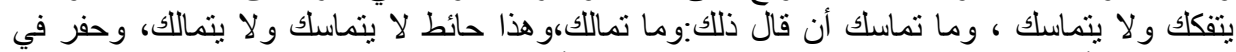

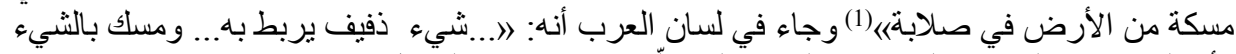

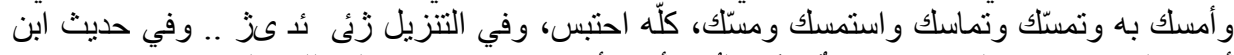

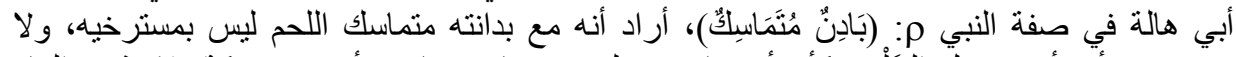

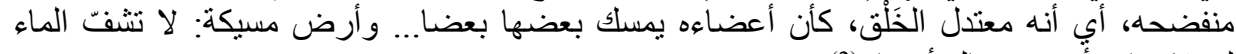

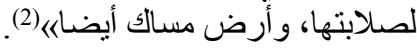

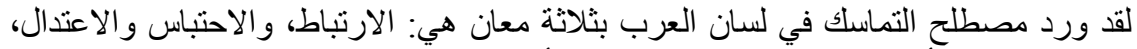

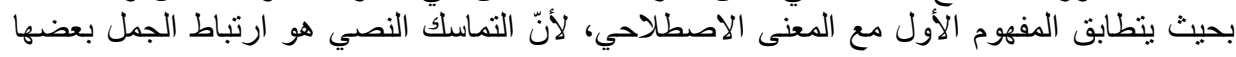

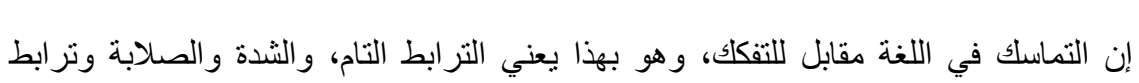
بeعض.

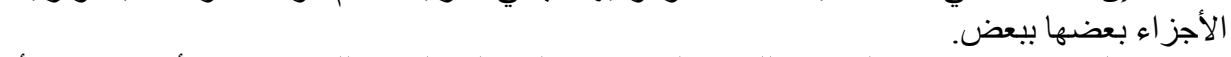
ولم ترد الإثارة في المعاجم اللغوية إلى ارتباط التماسك بالنص اللغوي، سواء أكان منطوقا أم 
مكتوبا، بل إن مجاز استعماله مرتبط بالإنسان. 2-1-التماسك/|صطلاحا:

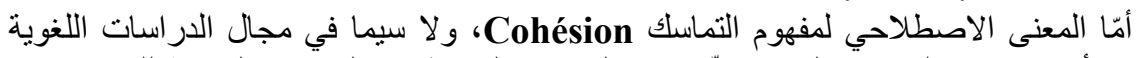

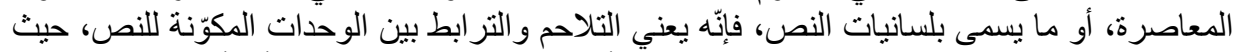

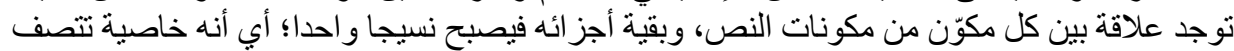

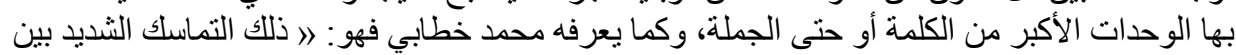

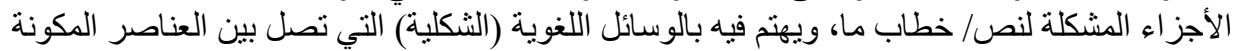

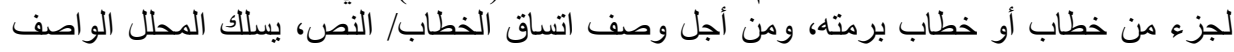

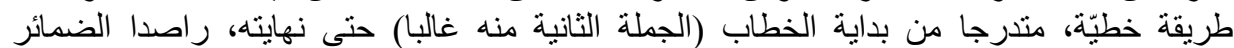

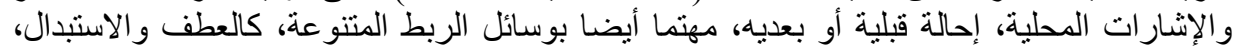

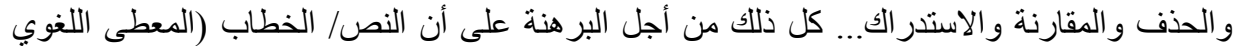

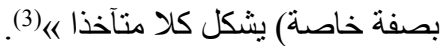

لهذا نجد أن الدر اسات النصية أولت التماسك عناية خاصة، لأنّه من خلال هذا المصطلح

يتم تمبيز النص عن اللانص.

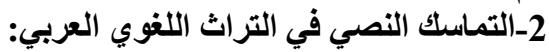

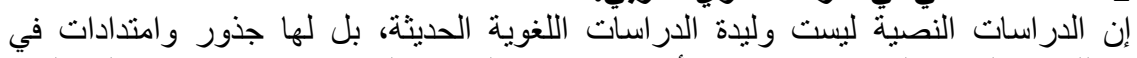

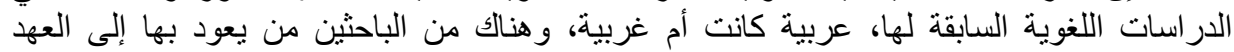

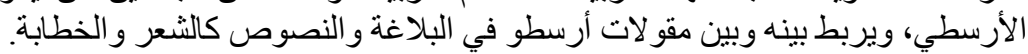

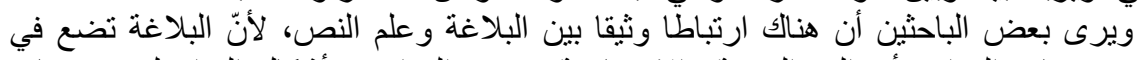

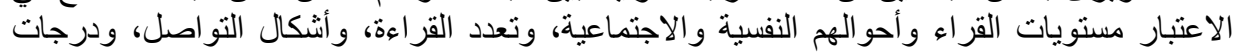

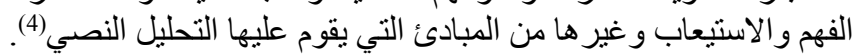

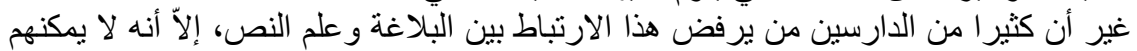

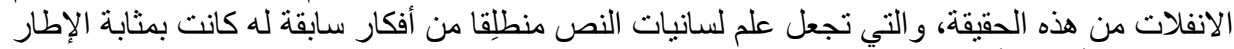

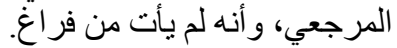

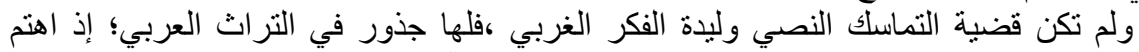

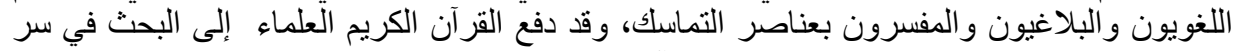

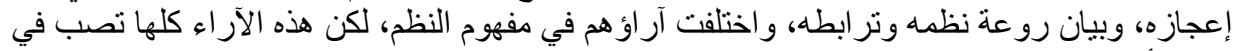
إطار تأسيس مفهوم التماسك. كما أدرك اللغويون العرب أن النص يجب أن يكون وحدة واحدة، وعبّروا عن ذلك بعبار ات

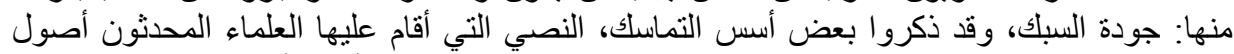

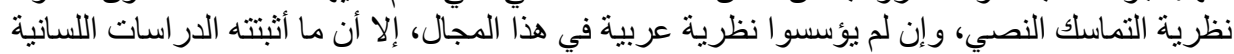

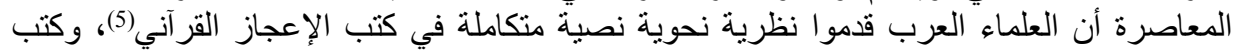

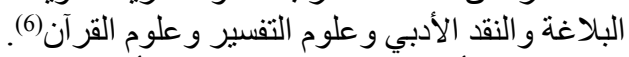

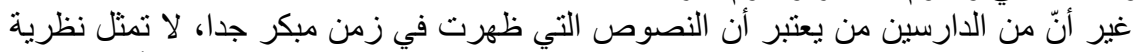

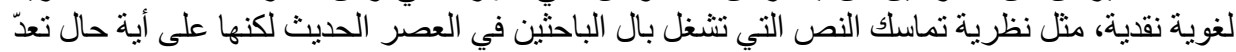

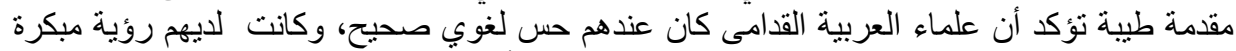

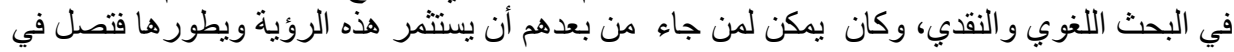

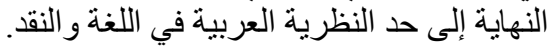

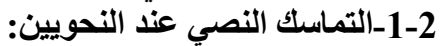

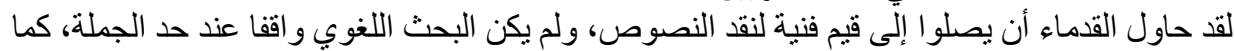

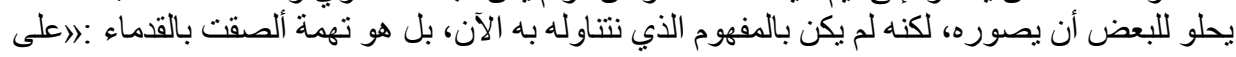


أننا ينبغي أن نعيد النظر فيما اتهم به بعض المحدثين نحاة العرب من أنهم قصروا جهودهم على نحو

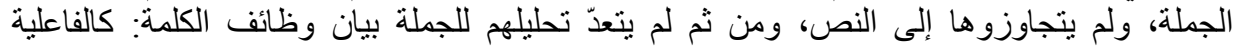

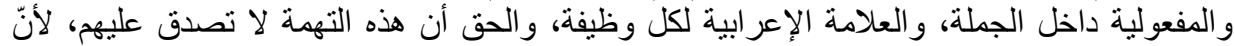

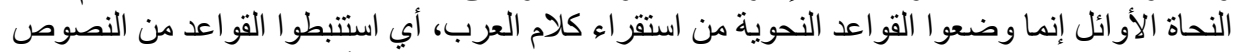

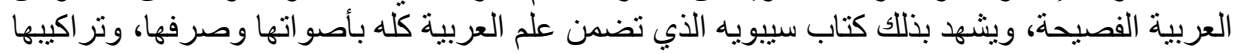

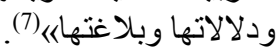

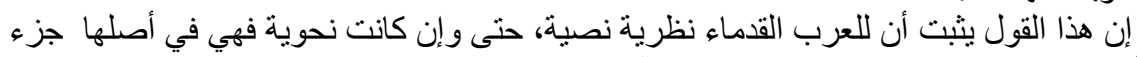

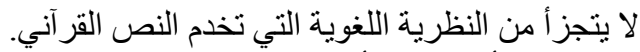
إلا أن هناك مأخذا يتنافى مع تقديم العرب الفئ القدماء لنظرية لغوية نصية متكاملة، خاصة و أنهم

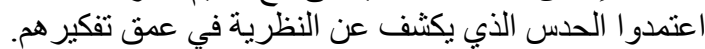

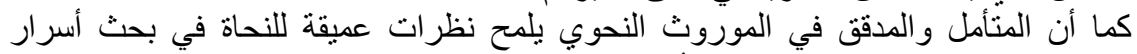

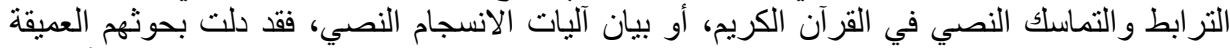

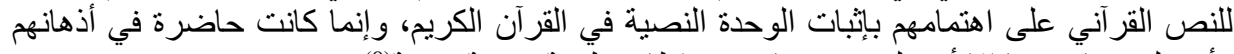

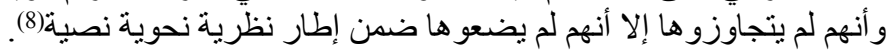

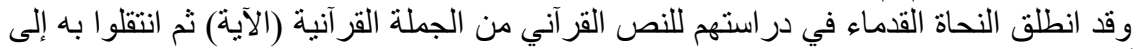

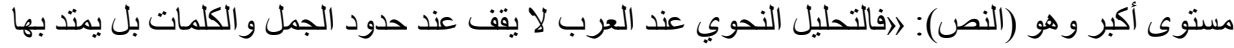
إلى العبارة وما بعدهای) (9).

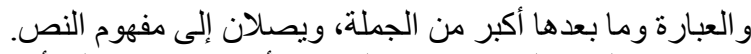

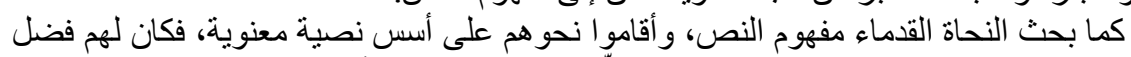

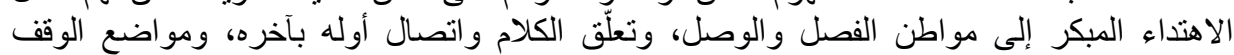

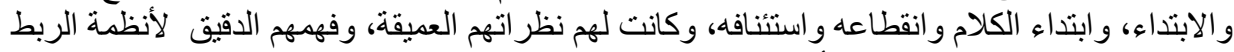

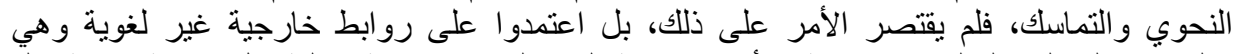

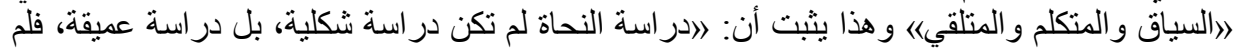

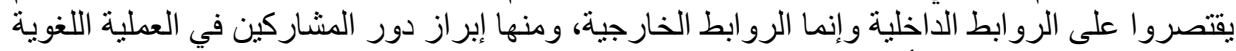

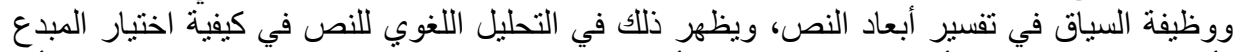

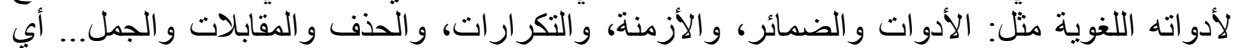

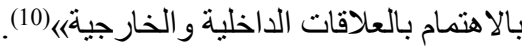

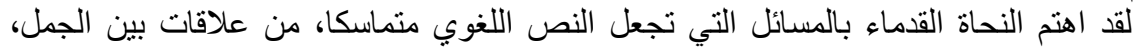
ودور المشاركين و السياق، وبالرو ابط الداخلية والخارجية.

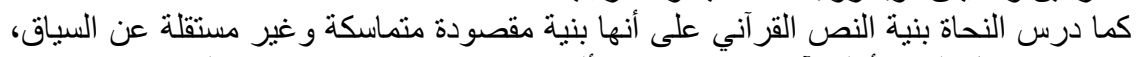

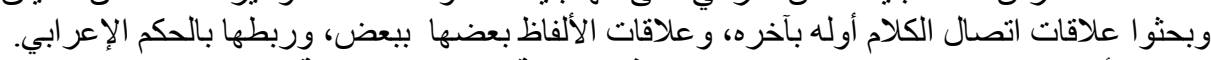

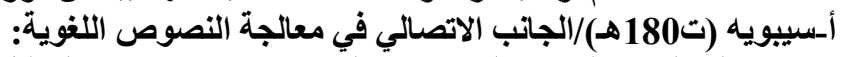

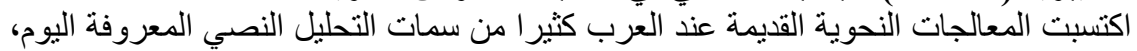

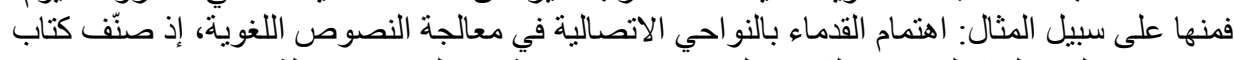

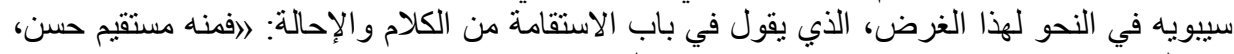

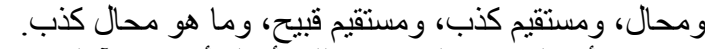

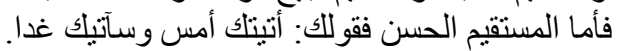

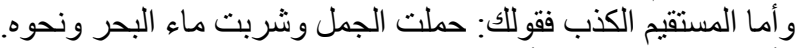
و أما المستقيم القبيح: فأن تضع اللفظ في غير موضعه نحو قوللك: قد زيدا رأيت، وكي زيدٌ يأتيك

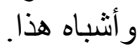

و أما المحال الكذب فأن تقول: سوف أشرب ماء البحر أمسيه(11). إنّ قول سييويه يحوي بعضا من خصائص النحليل النسل النصي منها: 
1-عدم الاقتصار على النواحي التركيية والإعراب في معالجة اللغة، بل يتعداها إلى النواحي

2-الاهتمام بالجانب الاتصالي كما يفعل علماء النصبة اليوم، وذلك من خلال اهتمامه بمناسبة

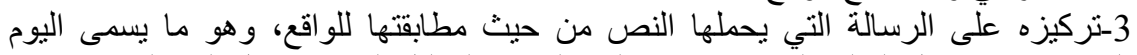

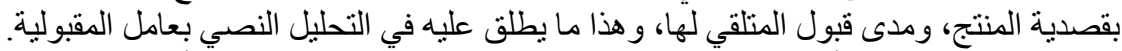

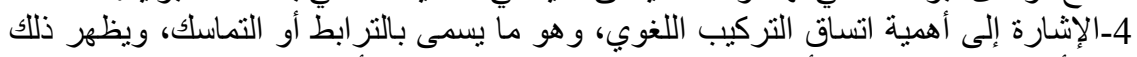

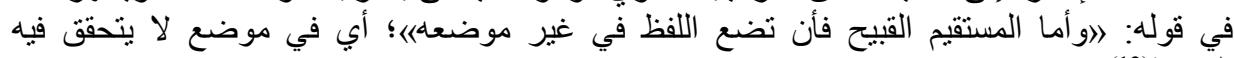

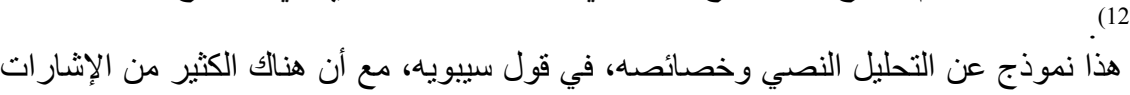

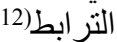

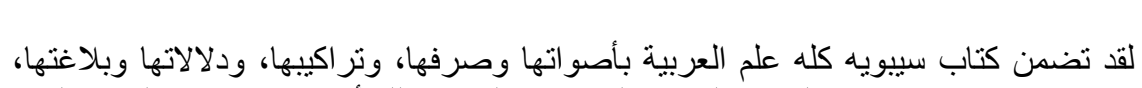

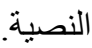

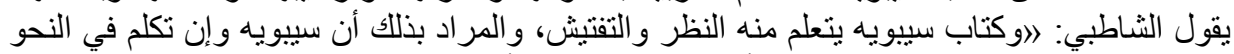

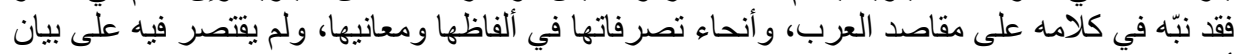

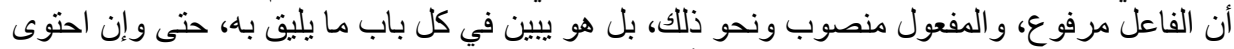

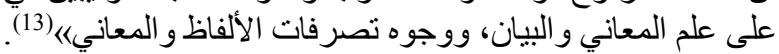

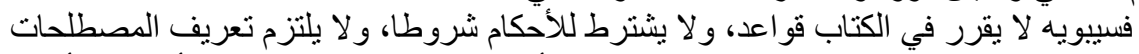

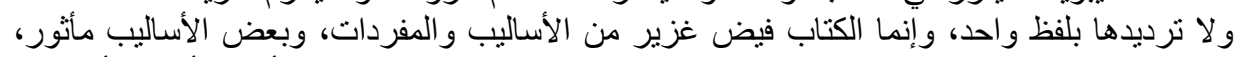

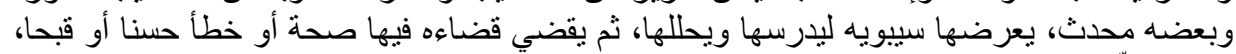
كثرة أو قلّلة، و وكذنا (14). لم بعالج كتاب سيبويه قضايا الأصوات ولات والصرف و النحو فقط، بل تعرض في في ثنابا ذللك، كله

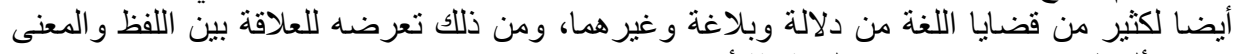

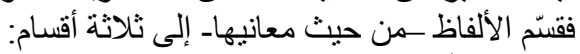

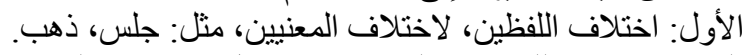

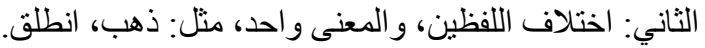

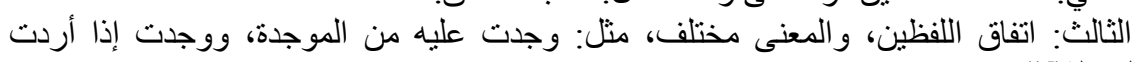

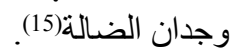
و هذا ما تعرض له علماء اللغة قديما وحديثا في علم الدلالة، حيث درسوا التباين، والترادف، و المشترك اللفظي.

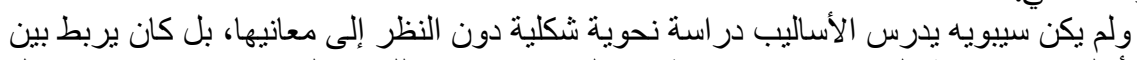

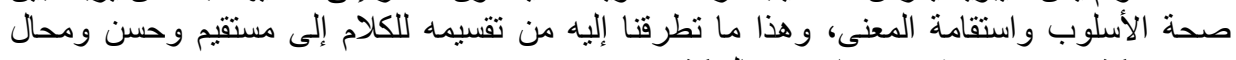

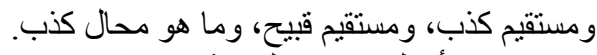

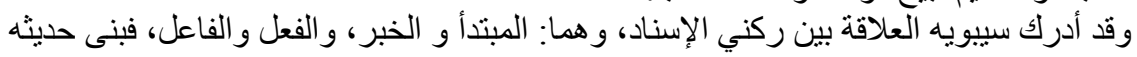

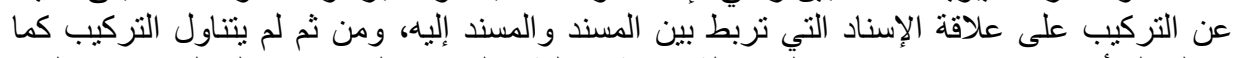

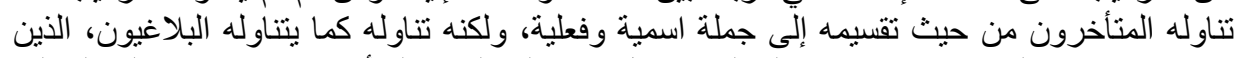

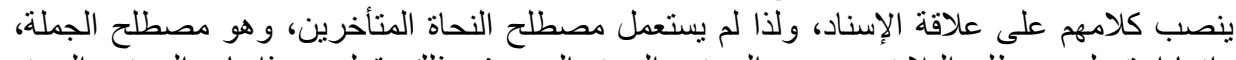

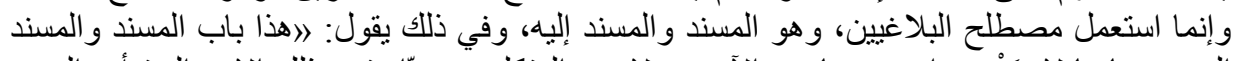

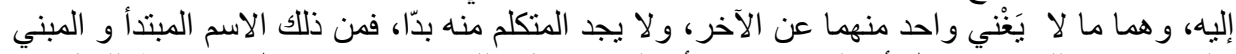

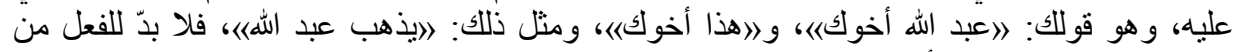

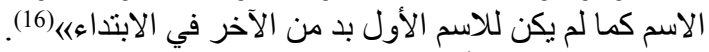

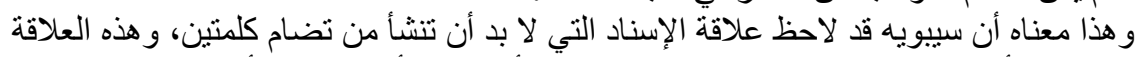

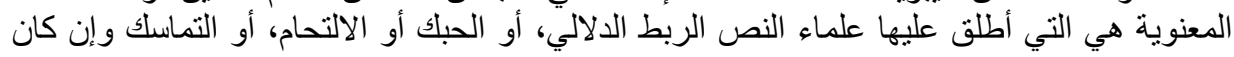


على مستوى الجملة التي هي نواة النص.

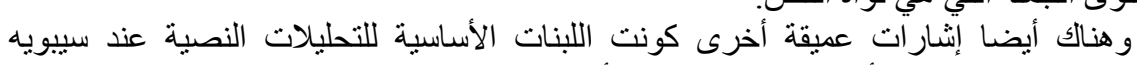

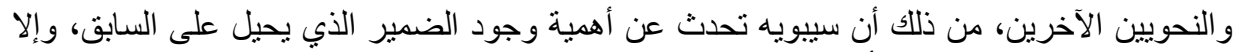

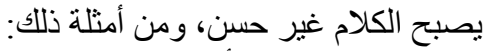

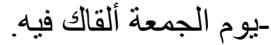

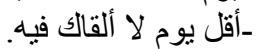

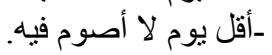

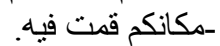

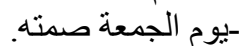
حيث كان المضمر -الهاء، هو الأول [يوم الجمعة] ولا يحسن في الكلام أن يجعل الفعل مبنيا

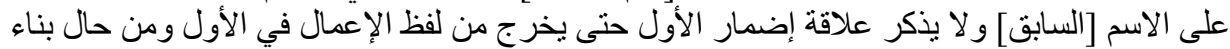

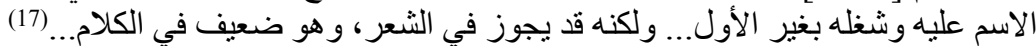
ويعلّق السير افي في الهامش قائلا: ارحذف الهاء يكون في ثلاثثة مواضيع: في الصلة و الصفة و الخبر .. وحذفها في الخبر قبيحهان(18). فقد وقف الإعمال من عدمه على وجود الضمير من على عدمه، فوجود الضمير الر ابط بين المعمول قابلت عليا وزيدا رأيته الغئه ويذكر سيبويه أنه 》اختير النصب ها هنا لأن الاسم الأول مبني على الفعل، فكان بناء الآخر على الفعل أحسن عندهم....) (20). هذه أمثلة تمثل إحالات قبلية عند سيبو يه، وهي من صميم التحليل النصي عند النحاة القدماء.

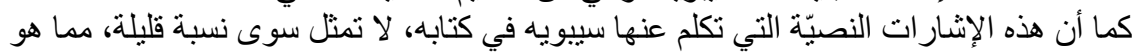

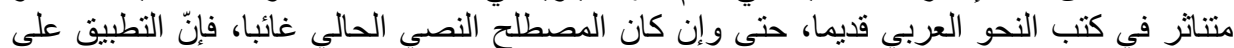

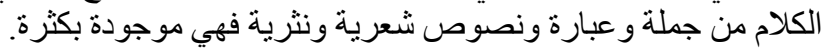

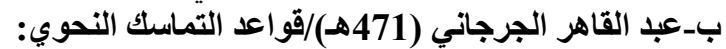

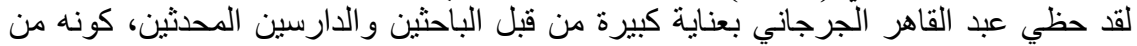

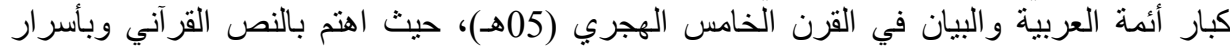

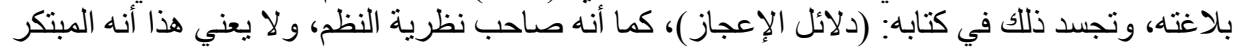

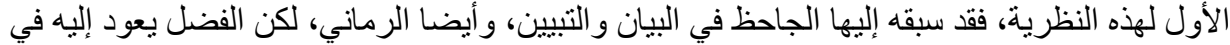

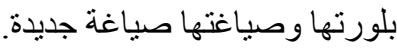

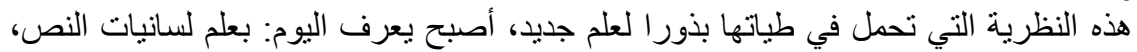

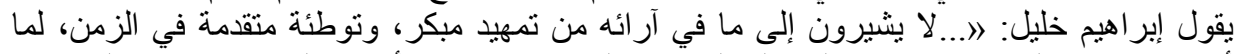

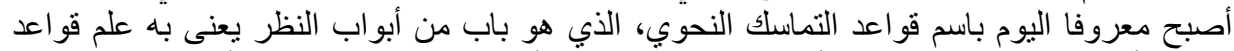

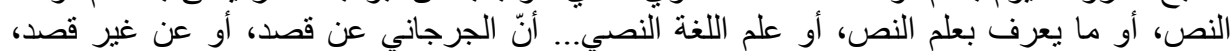

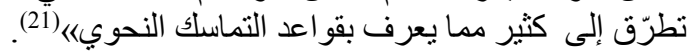

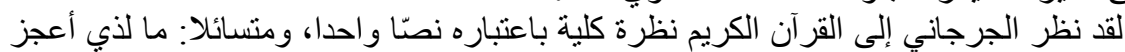

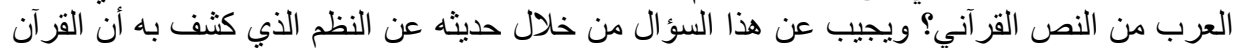

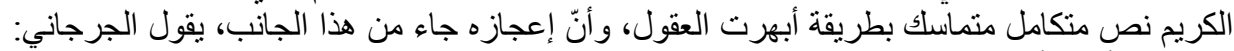

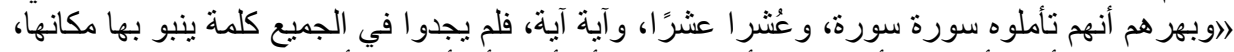

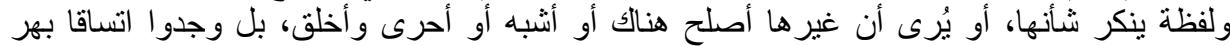

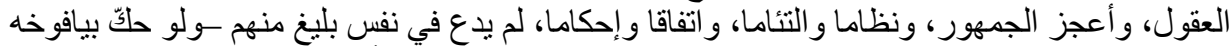

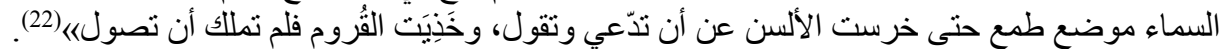
وما بلاحظّ على نص الجرجاني أنه نظرة كلية إلى النص القر آني، ثم اتبع ذلك ذكر مصطلحات 


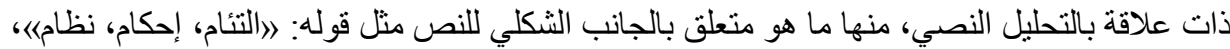

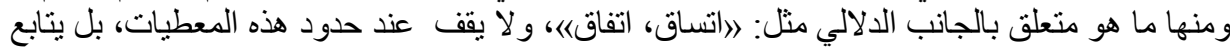

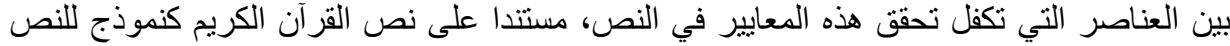

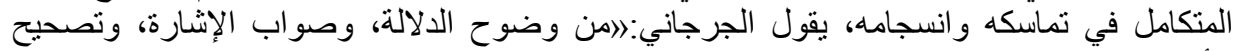

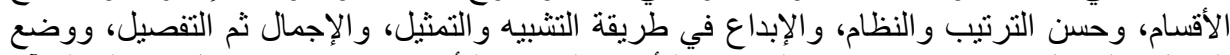

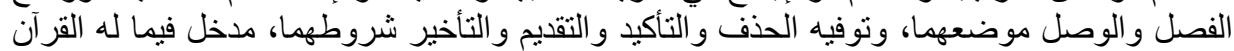

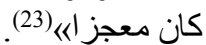

طبق الجرجاني نظرية النظم على النص القر آني، ليجعل منه نصّّا إعجازيا تقف عند عنده العقول

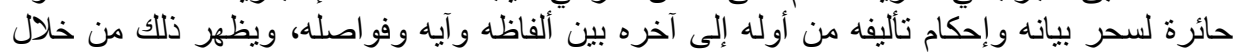

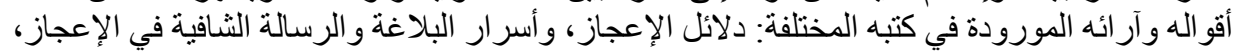

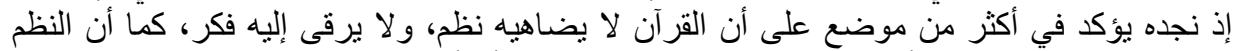

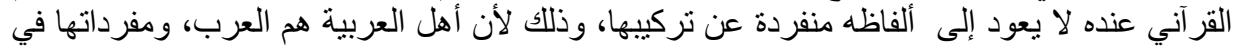

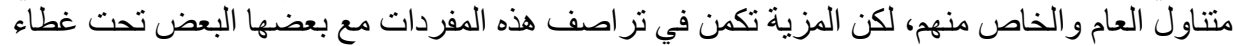

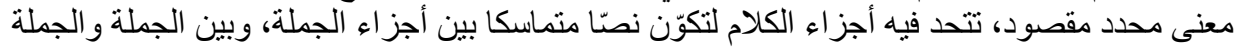

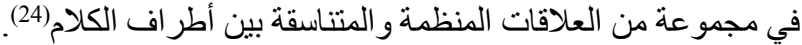

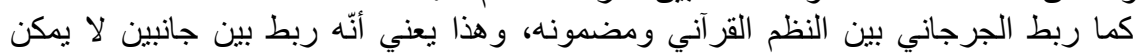

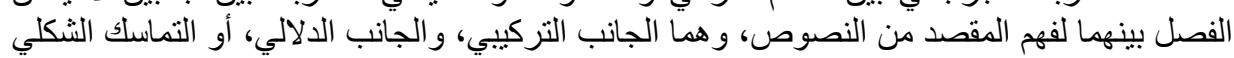

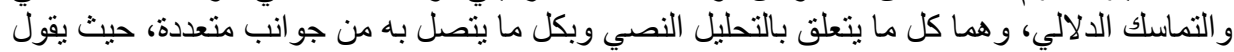

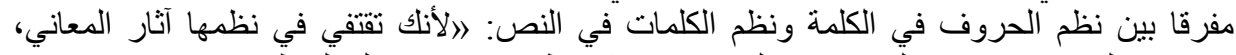

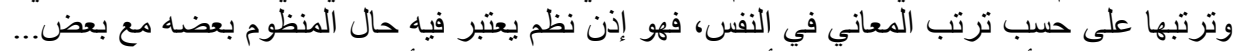

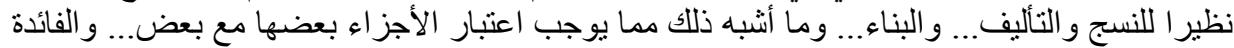

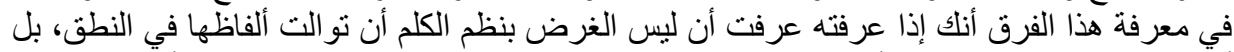

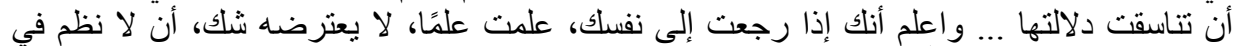

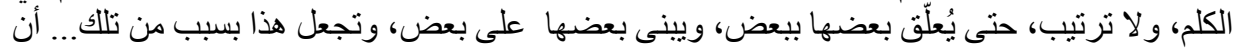

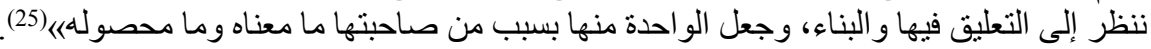

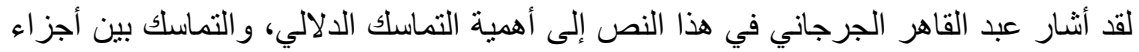

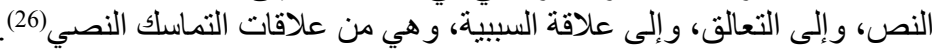

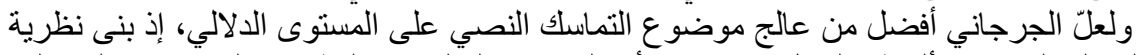

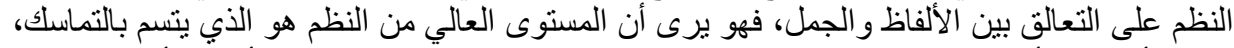

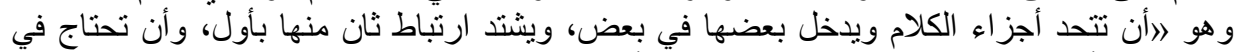

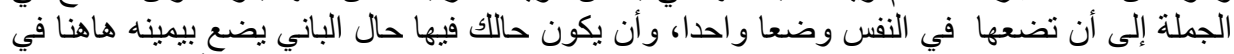

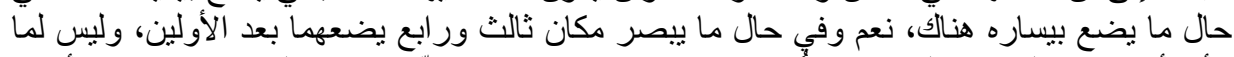

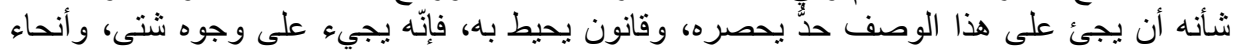
مختلفة/) (27)

و هذا معنى آخر للتماسك بصورة أوضح، مما نجده في النظريات اللسانية الحديثة المهتمة

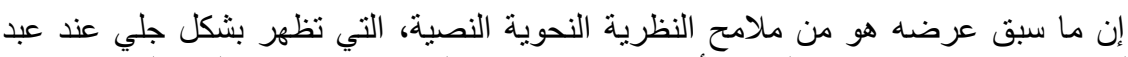

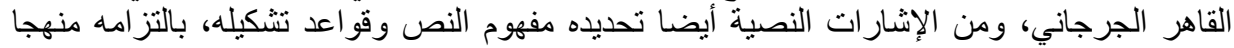

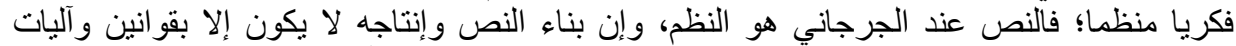

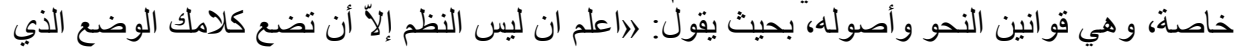

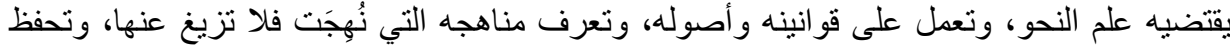
الرسوم التي رُسمت للك فلا تخلَّ بشيء منها...به (28). 
فهذه جملة من القو اعد ذكرها الجرجاني، ليصف من خلالها القيود التي يلتزمها المتكلم في تأليفه

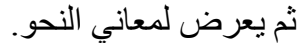

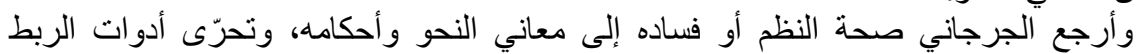

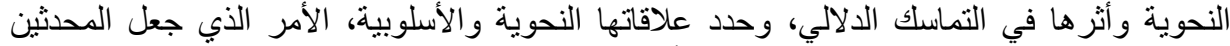

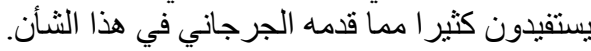

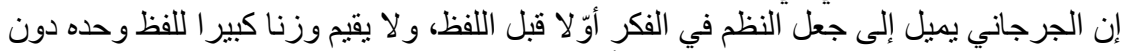

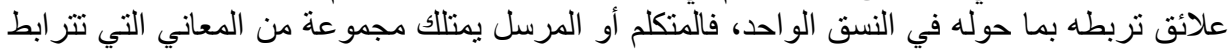

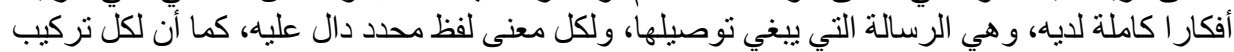

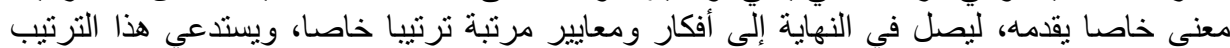

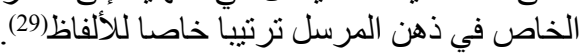

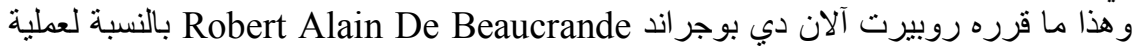

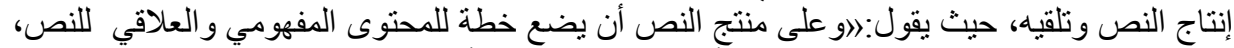

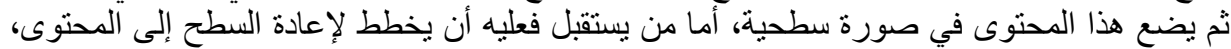

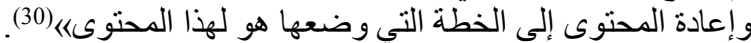

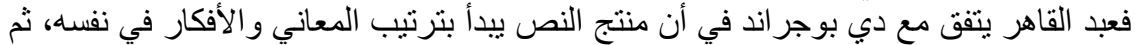

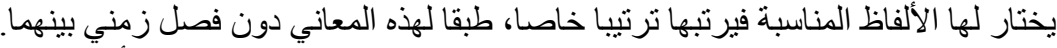

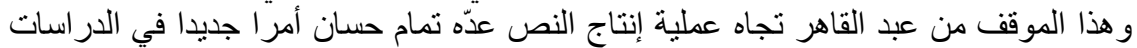

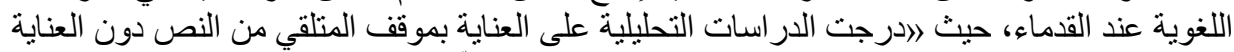

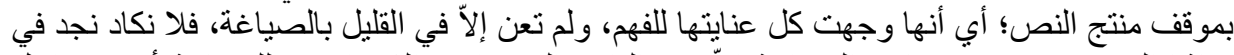

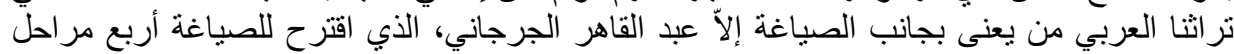

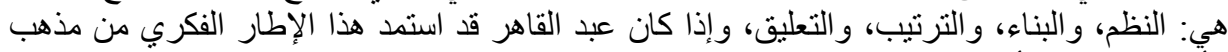

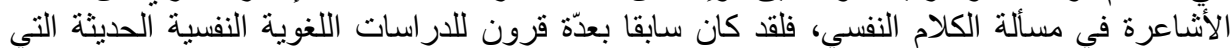
تنتاول إنتاج النص اللغوي) (31).

ومن مظاهر التماسك النصي عند عبد القاهر الجرجاني، والتي اتخذت طابعا فكريا ومنهجا

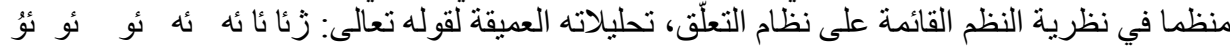

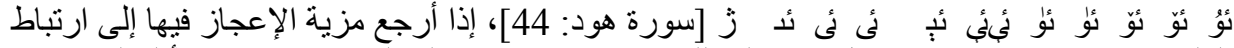

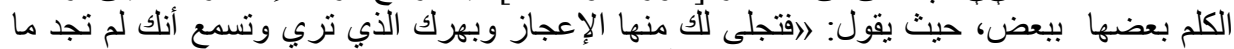

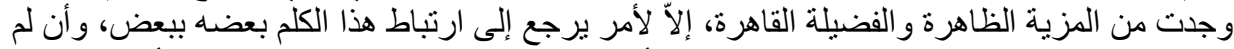

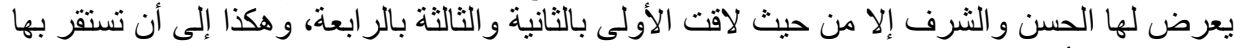

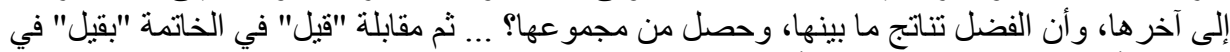

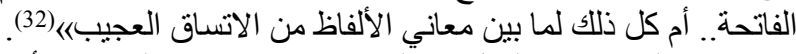
و وعليه فيمكنا القول إن ألجرجاني في نظرية الناطي النظم، قد أثنار إلى الكثير من التحليلات النصية،

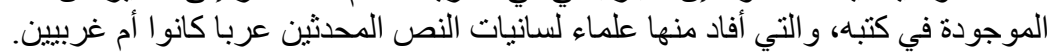

جـالفراء و ابن السرّاج و ابن هشام/الترابط النحوي النصي في القرآن الكريم:

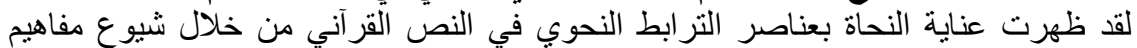

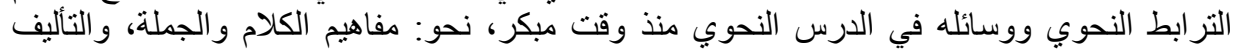

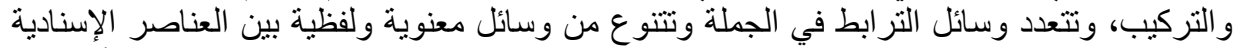

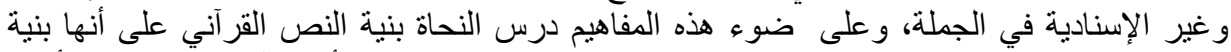

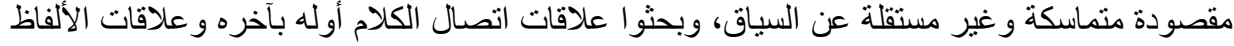
بعضها ببعض، وربطها بالحكم الإعر ابي (33).

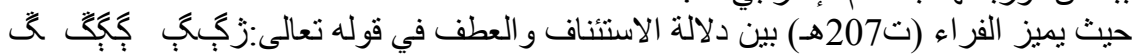




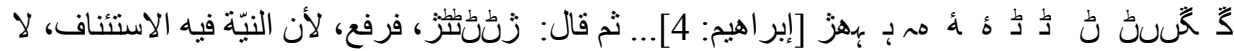
العطف على ما قبله (34).

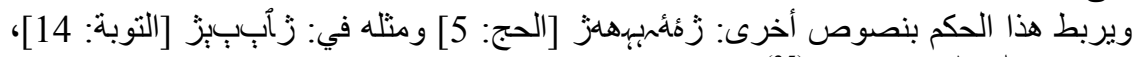
ثم قال: 》 ويتوب الله على من يشاءي) (35).

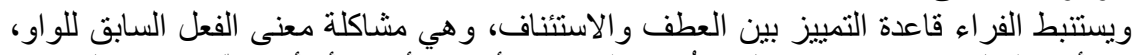

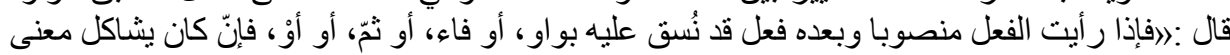

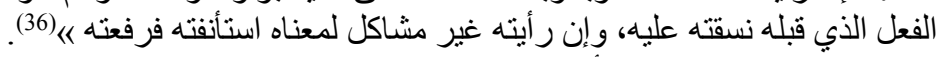

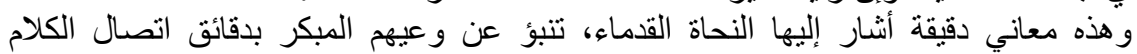

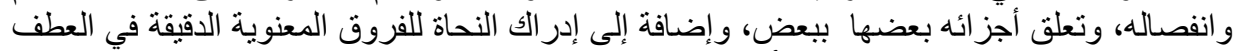

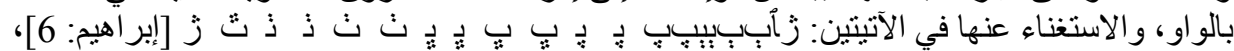

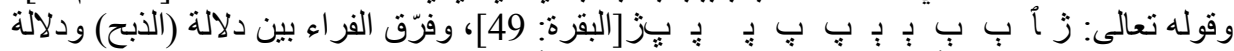

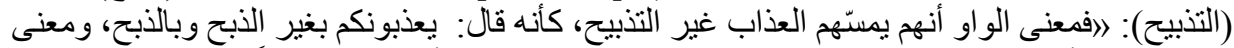

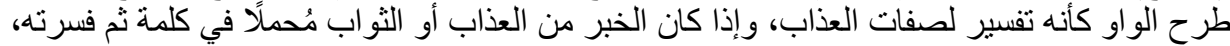

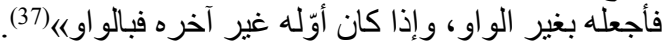

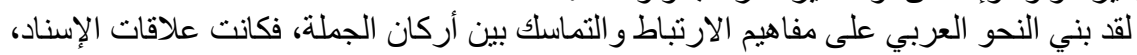

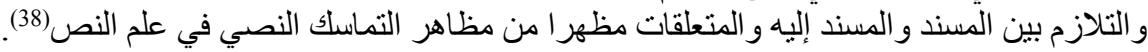

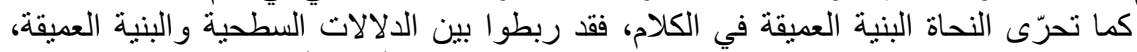

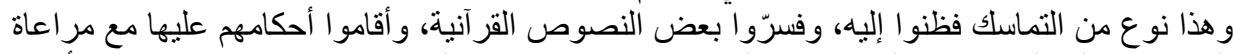

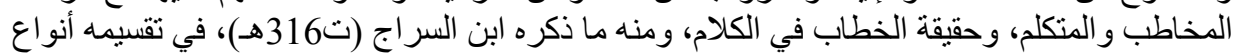

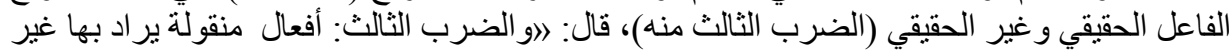

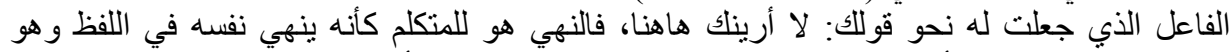

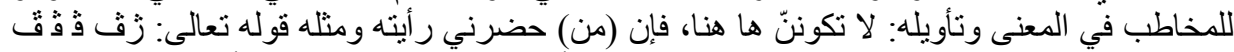

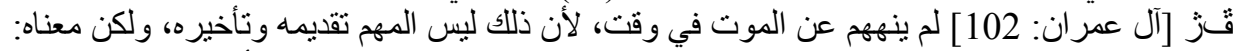

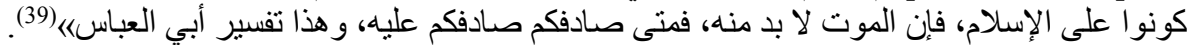

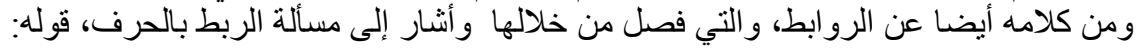

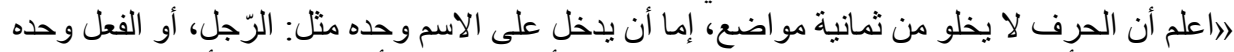

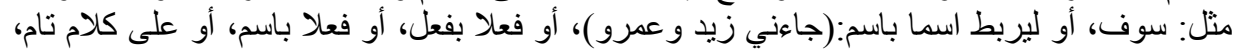

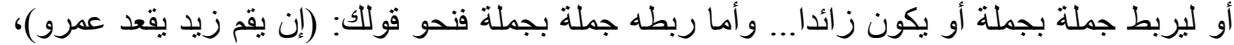

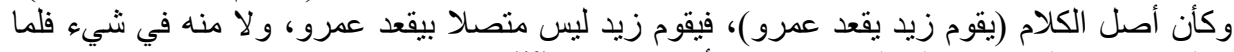

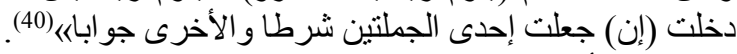

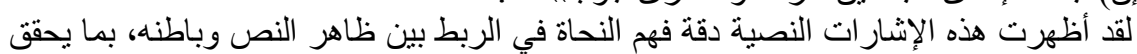

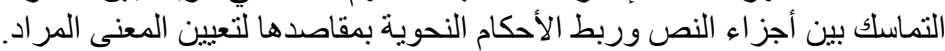

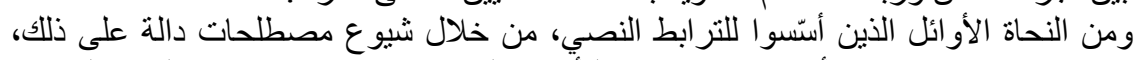

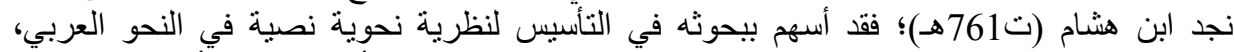

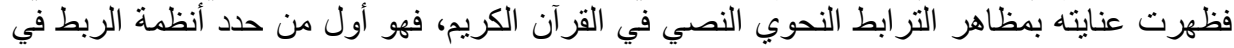

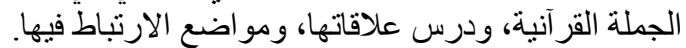

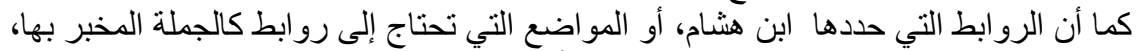

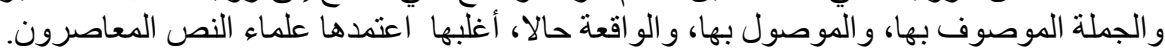

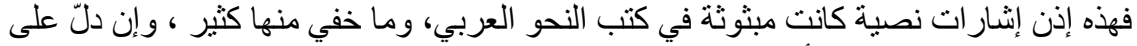
شيء فإنما يدل على النظرة الثاقبة لأمثال ابن هشام وغيره. 
2-2-2 التماسك النصي عند البلاغيين:

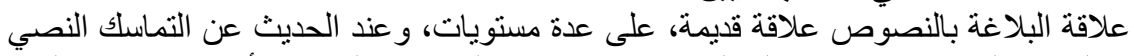

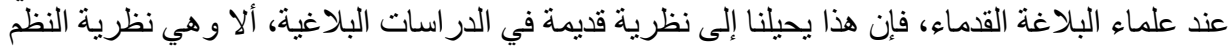

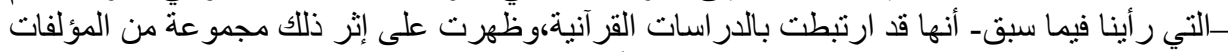

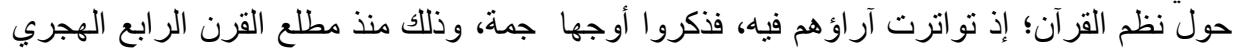
04 04هـنذكر منها على الترتيب: - إعجاز القرآن في نظمه وتأليفه لأبي عبد الله محمد بن يزيد الر ابطي (306هـ التهـ). ــظم القرآن لأبي بكر بن أبي داود الَّجستاني (316هـ). - نظم القرآن للجاحظ (255هـ). - إعجاز القر آن للباقلاني (403هـ).

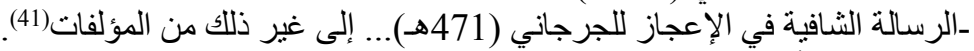

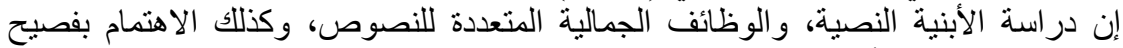

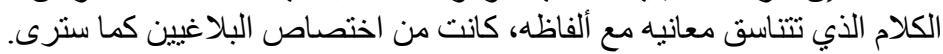

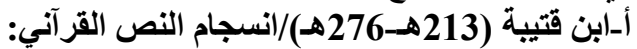

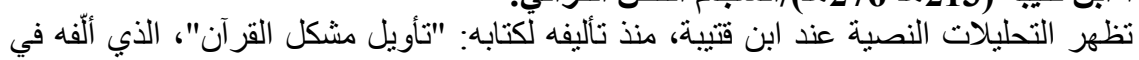

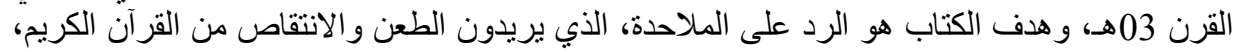

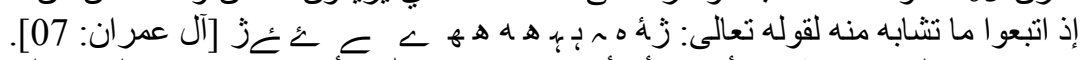

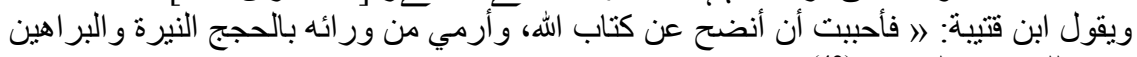
البينة و أكثف للناس ما يلبسونه) (42).

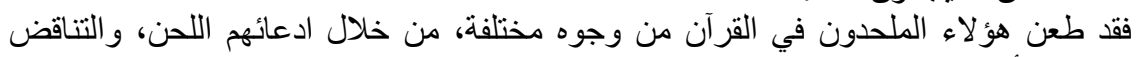

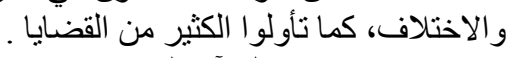

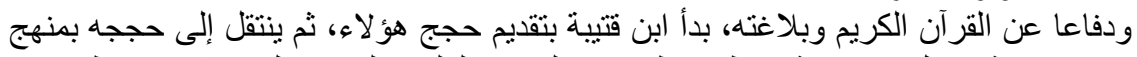

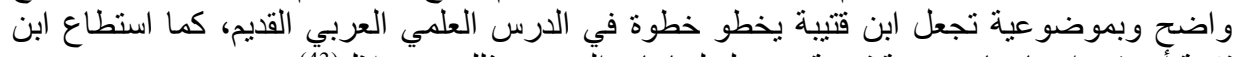

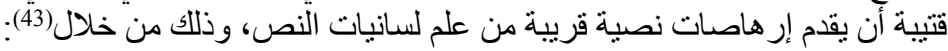

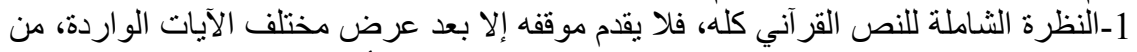

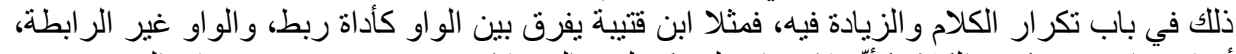

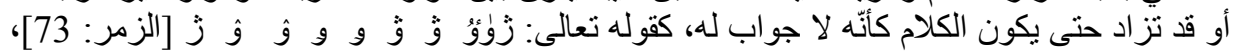

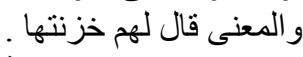
كما كان ابن قتنيبة يهتم بدور أدوات الربط في اتساق النّص.

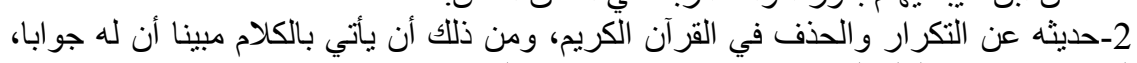

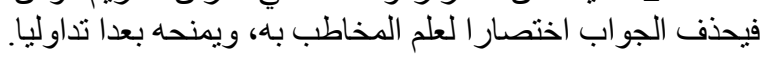

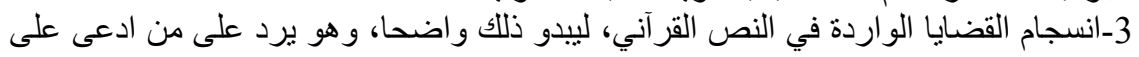

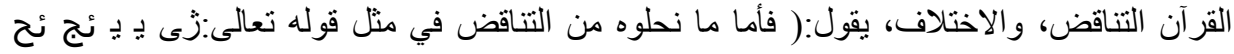

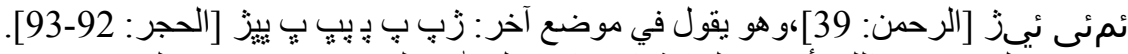

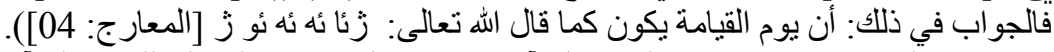

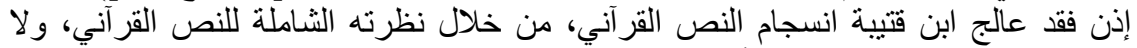
يتحقق هذه الثمولية إلا مثل النماذج التي أوردناها في النقاط الثناث النيان السابقة.

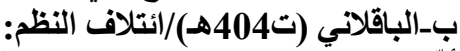

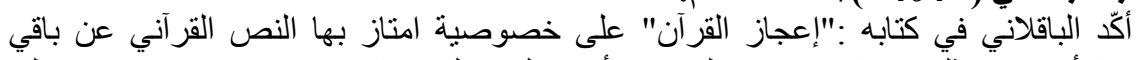

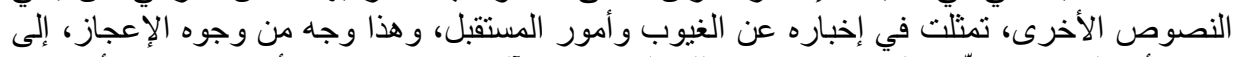

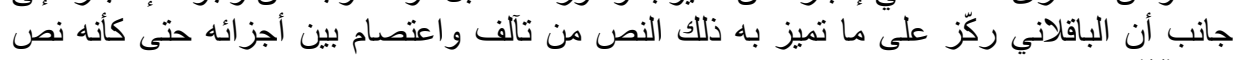


وفي هذا شيئان: الأول: الوقوف على سر الإعجاز القرآني، والثاني: الإشارة إلى ما في كتاب

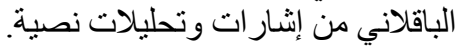

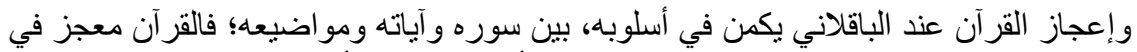

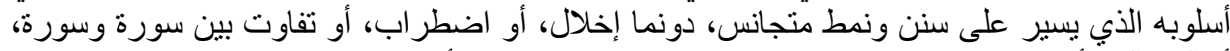

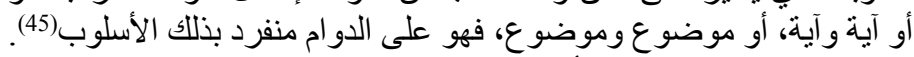

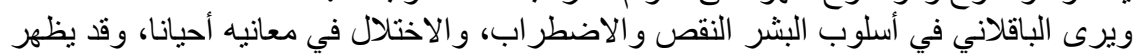

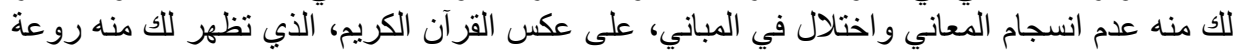

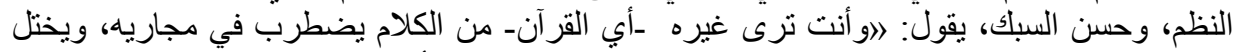

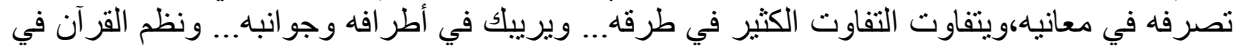

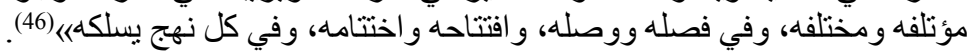
هذا القول فيه الكثير من الإشار ات النصية في القرآن آلكريم، من ذللك، ائتلاف النظم، أبي تماسكه

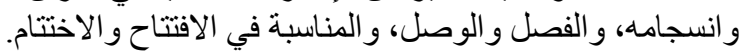

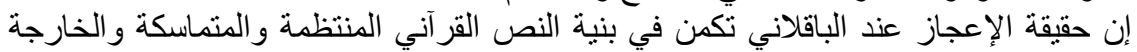

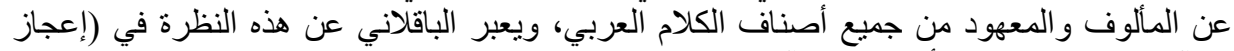

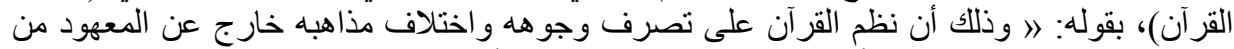

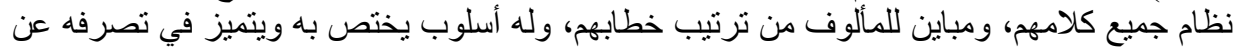

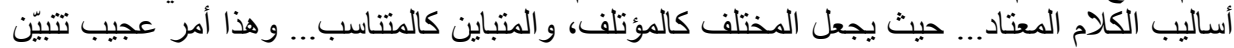
في الفصاحة وتظهر في البلاغةنة) (47).

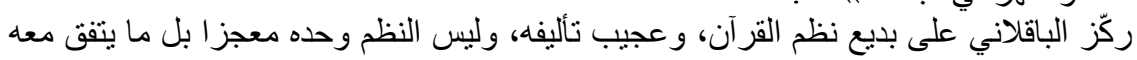

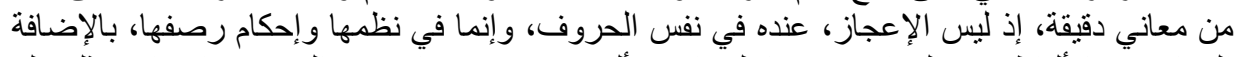

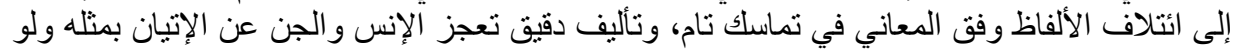
كان بعضهم لبعض ظهير الألفاظ (48).

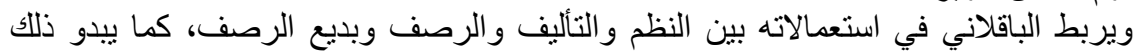

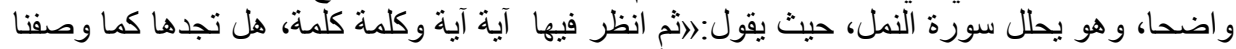

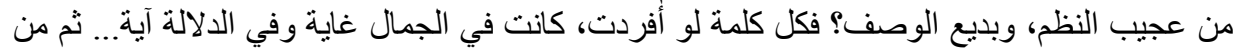

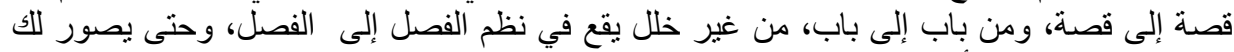
الفصل وصلا بيديع التأليف وبليخ التنزيلهاب(49).

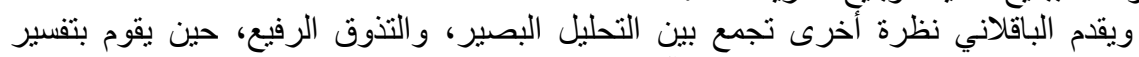

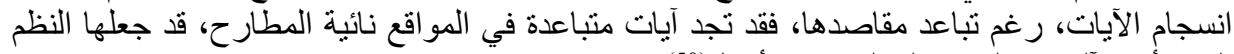

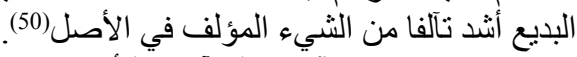

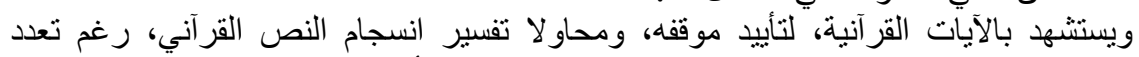

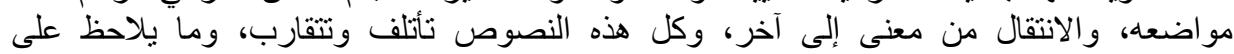

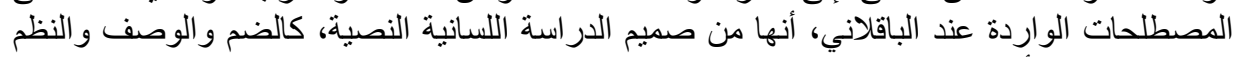

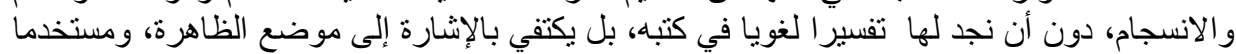

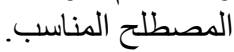

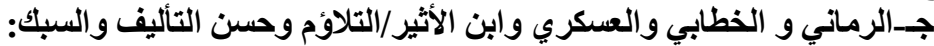

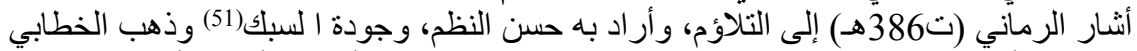

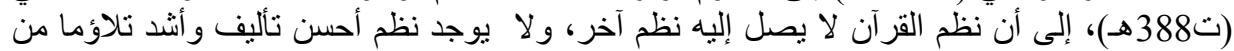

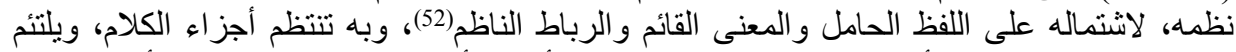

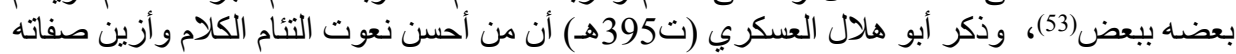

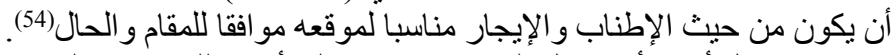

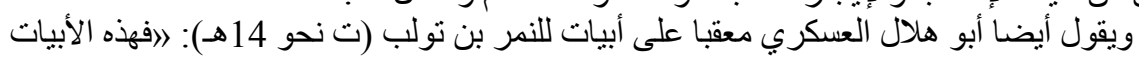




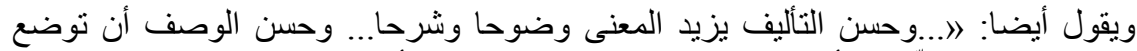

جيدة السبك حسنة الرصفي(55).

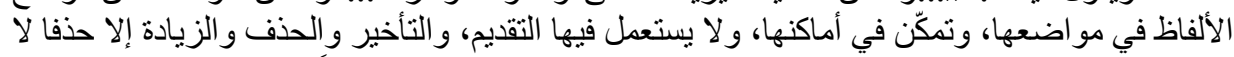

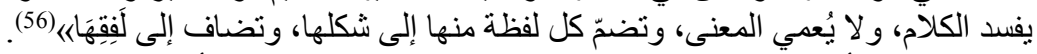

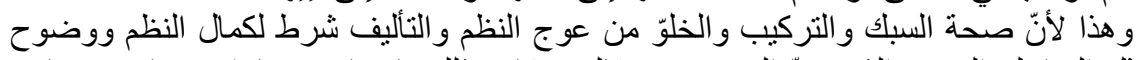

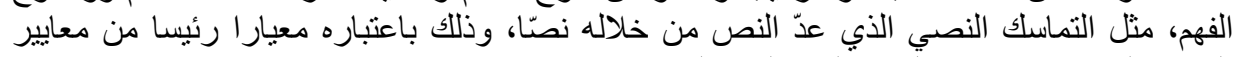

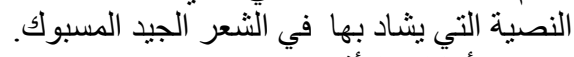

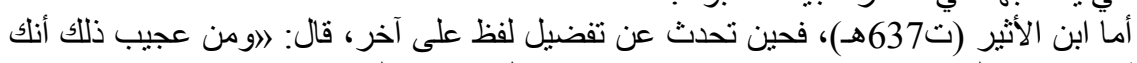

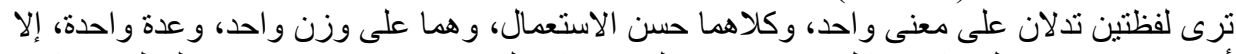

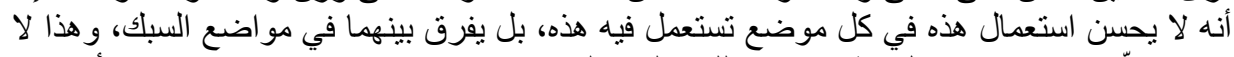

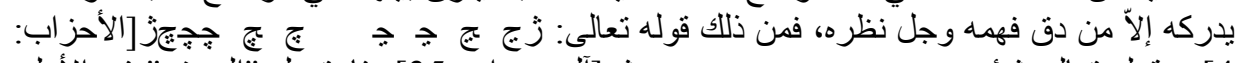

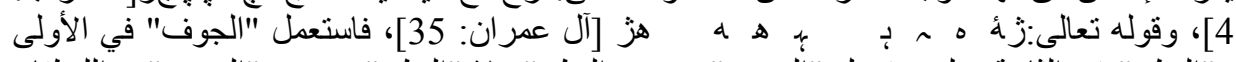

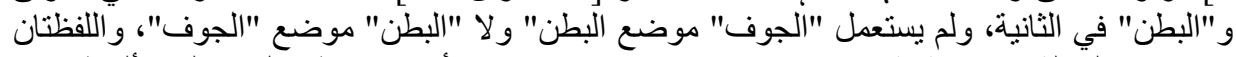

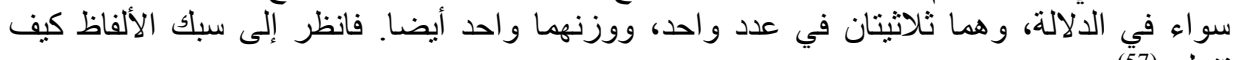

\section{3 الخلاصة:}

$$
\text { تفعلی) (57). }
$$

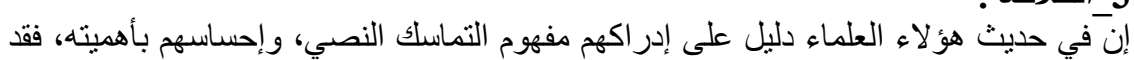

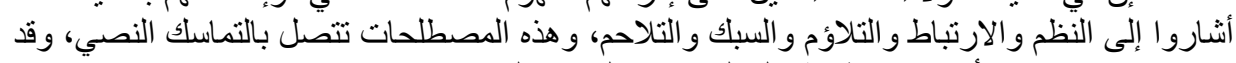

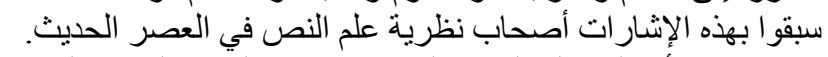

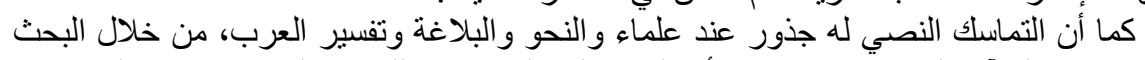

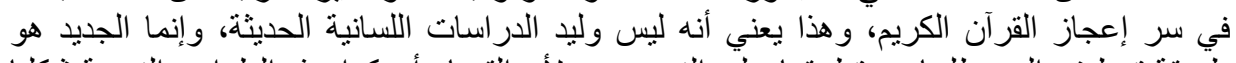

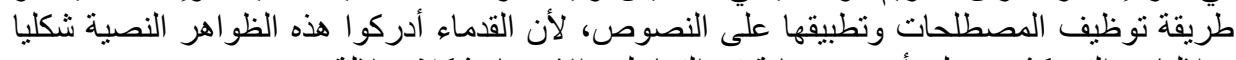

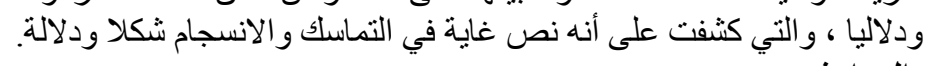

ـالهوامش: ودلاليا:

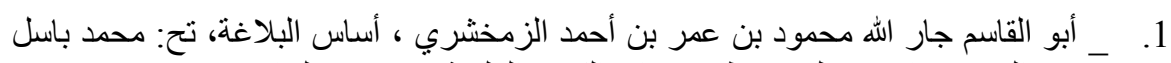

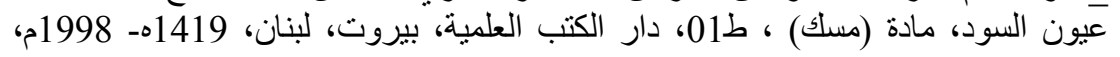

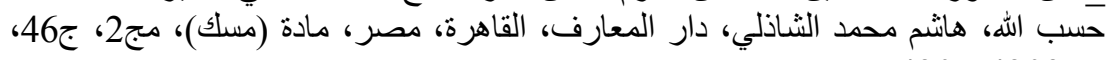

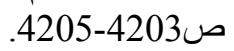

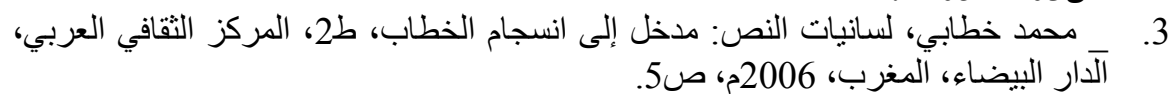

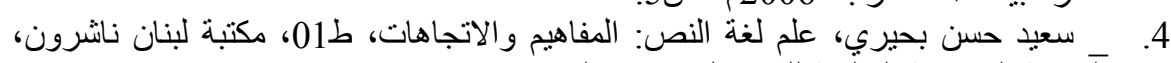

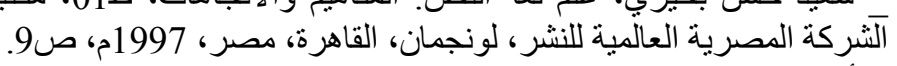

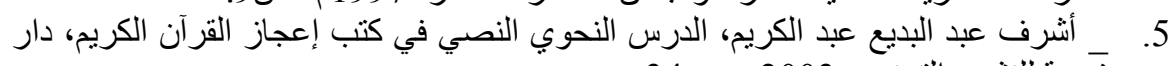

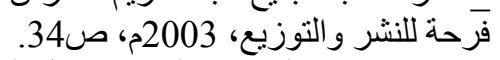

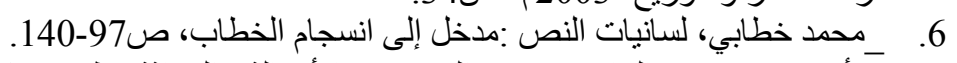
7.

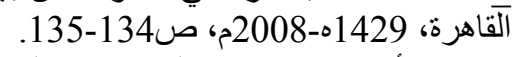

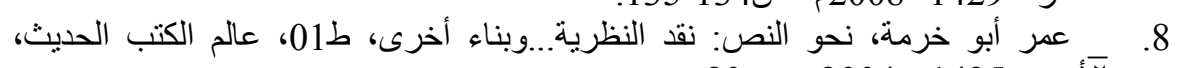

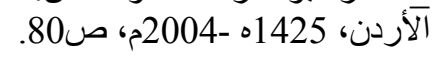


9. ـ حسين خمري، نظرية النص:من بنية المعنى إلى سيميائية الدال، ط1، الدار العربية للعلوم

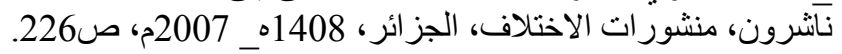

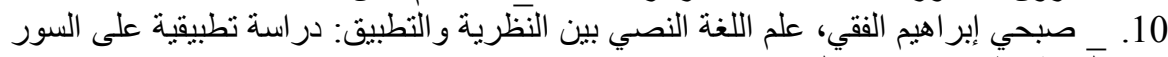

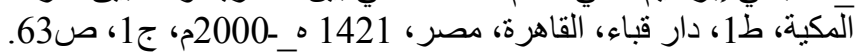

11. _ سييويه، الكتاب، تح: عبداه السارة السلام عبد، السلاّم محمد هارون، مكتبة الخانجي، القاهرة،

26-25 1988-01408

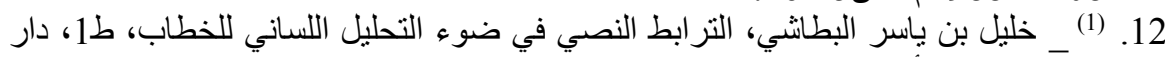

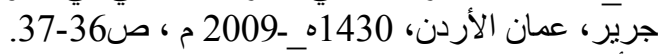

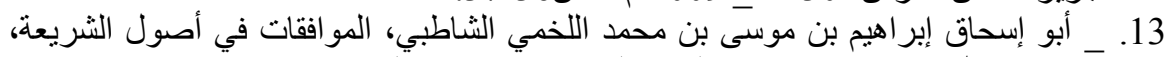

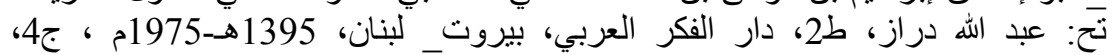

ص116.

14. _ علي النجدي ناصف، تاريخ النحو، دار المعارف، القاهرة، 1978م ، ص19.

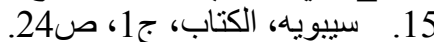

16. - المصدر نفسه، ج1، ص23.

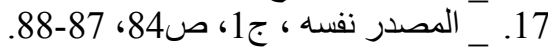

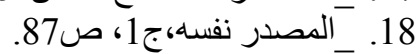

19. _ــصبحي إبر اهيم الفقي، علم اللغة النصي بين النظرية و التطبيق: دراسة تطبيقية على السور

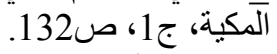

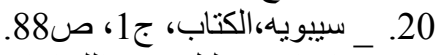

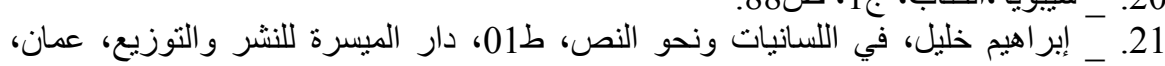

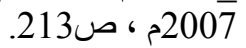

22. _. عبد القاهر الجرجاني، دلائل الإعجاز، تح: محمود محمد شاكر، ط05، مكتبة الخانجي،

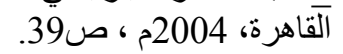

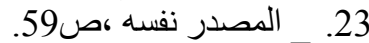

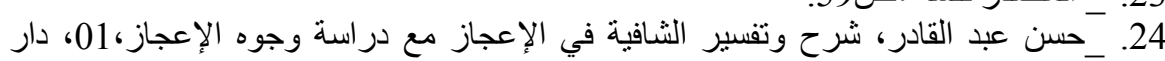

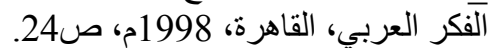

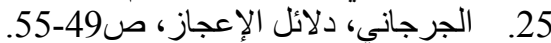

26. (َصبحي إبراني، دالفيم الإعجي، علم اللغة النصي بين النظرية و التطبيق: دراسة تطبيقية على السور

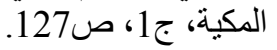

27. _الجرجاني، دلائل الإعجاز، ص93.

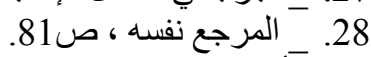

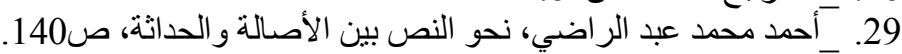

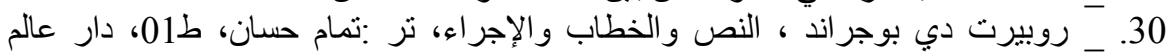

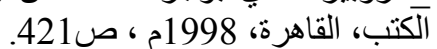

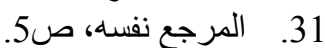

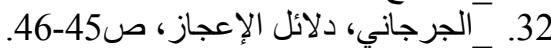

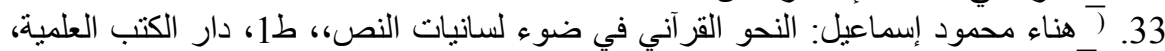

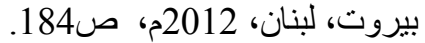

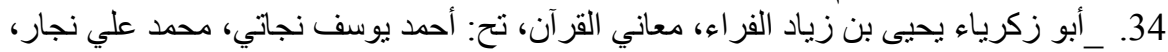

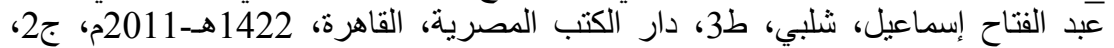

ص67.67.

35. _ _ المصدر نفسه، ج2، ص ن. 


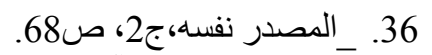

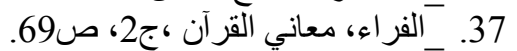

38. _ــبحي إبر اهيم الفقي، علم اللغة النصي بين النظرية و التطبيق: دراسة تطبيقية على السور

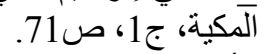

39. ـأبو بكر محمد بن سهل بن السراج النداج النحوي البغدادي، الأصول في النحو، تح: عبد الحسين

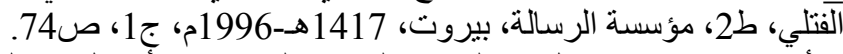

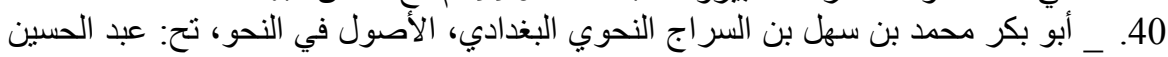

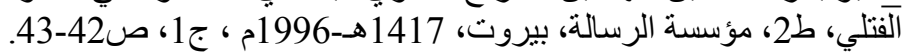

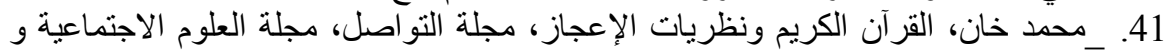

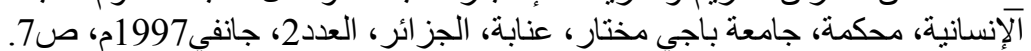
42. _ابن قتتية، تأويل مشكل القر آن، تح: السيد أحمد صقر، ط3، المكتبة العلمية، المدنية المنورة،

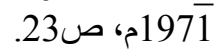

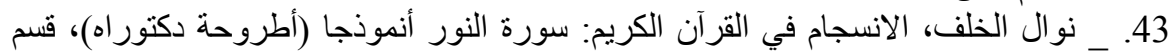

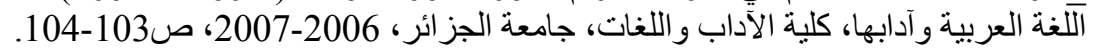

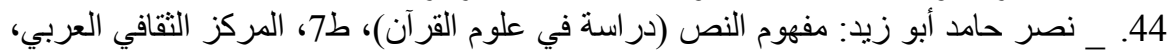

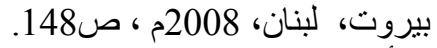
45. _ أبو بكر محمد بن الطيب الباقلاني، إعجاز القرآن، تحقيق: أحمد صقر، دار المعارف،

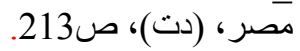

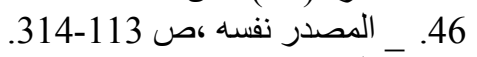

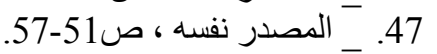

48. _ـحسن عبد القادر، شرح وتفسير الثنافية في الإعجاز مع در اسة وجوه الإعجاز ، ص227.

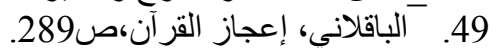

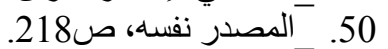

51. _ _الرماني، الخطابي، الجرجاني، ثلاث رسائل في إعجاز القرآن، تح: محمد خلف الله،

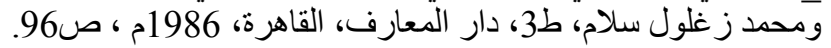

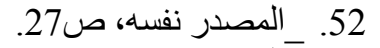

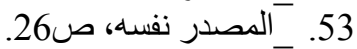

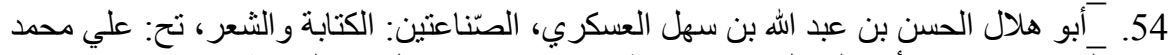

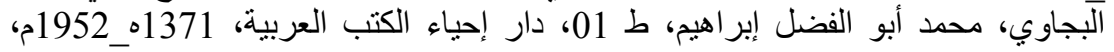

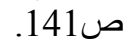
55. 5 ـ الدصدر نفسه ، ص169 ص161. 56. - المصدر نفسه، ص161.

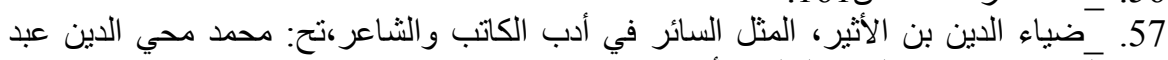

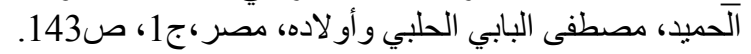

